\title{
The Nordic Countries as a Historical and Historiographical Region: Towards a Critical Writing of Translocal History
}

\author{
Marja Jalava \\ marja.jalava@helsinki.fi \\ Academy Research Fellow \\ University of Helsinki \\ Department of Philosophy, History, Culture and Art Studies \\ P. O. Box 4 (Porthania) \\ Finland
}

\begin{abstract}
This article focuses on the recently increased interest in transnational and translocal regions and regionalism in the context of a general "spatial turn" in the social sciences and the humanities. Using the historical conceptualizations of "the North" and "the Nordic region" (Norden, Pohjola) as an example, the article analyzes the processes of region-building in general and the case of the Nordic countries (Scandinavia) as a historical and historiographical region in particular. On the one hand, the constructed character of Norden will be acknowledged; on the other, it is also argued that the regional constructions may have a certain degree of construct validity and a historical continuity, based on common historical experiences and the inherent spatiality of history. Finally, the article concludes that the acknowledgement of the transnational framework is important when rethinking the history of historiography, albeit it is not necessarily a more "enlightened" alternative

244 to methodological nationalism.
\end{abstract}

Keywords

History of historiography; Regionalism; Space.

Received in: 6/29/2012

Approved in: 10/31/2012 


\section{"The Nation Is Dead, Long Live the Region"?}

In an article published in 1984, entitled "Die Nation ist tot: Es lebe die Region," the German historian Hans Mommsen questioned the self-evident position of the nation-state at the hub of historical research (MOMMSEN 1984). Such an interest in a transnational or regional framework was by no means new. In the early nineteenth century, the establishment of geography as an academic discipline encouraged scholars within cultural sciences to elaborate wide-ranging theories about the relationship between human history and physical environment, transcending the present state borders. Although the growth of historicism in academic historical research diminished the interest in the concept of space, which was mainly considered a neutral and passive stage for historical actors, the turn of the century saw the "return of space". Broadly speaking, this rehabilitation of the concept of space was boosted by the colonial globality of high imperialism which resulted in the invention of new spatially oriented academic disciplines such as anthropogeography and geopolitics as well as new transnational concepts such as Lebensraum ('living space'). At the same time, pan-Asiatic and pan-Islamic movements developed outside Europe to oppose the Eurocentric conception of the global space (SMITH 1991, p. 5659, 219-231; CONRAD 2010, p. 60-66).

Nevertheless, both in Europe and elsewhere in the world, the late nineteenth-century process of globalization was accompanied by the creation of new nation-states. Thus, to cite the German historian Sebastian Conrad, "global interconnectedness did not so much contribute to the dissolution of nation-states, as some contemporary commentators believed, but rather was instrumental in constituting them and making them permanent" (CONRAD 2010, p. 67). The position of the nation-state as the self-evident spatial unit of historywriting was further consolidated by the fact that post-WWII social theories were particularly interested in modernization, development, and change - in other words, in temporality at the expense of spatiality. Indeed, in the Germanspeaking academe, even the very word Raum (space) became politically and ethically dubious, since geopolitics and the idea of Lebensraum had been used during the interwar period as a "scientific" justification for imperialism and Nazism with disastrous consequences (SOJA 1989, p. 34-38; SMITH 1991, p. 232-233). Although regional and transnational perspectives continued to exist in the margins of methodological nationalism (for instance, the Annales School and Marxist-inspired world-system analyses), there is no doubt that, at least in European historiography, the vast majority of historical studies until today has firmly resided within the parameters of nation-states. Even when history-writing has been conducted under the label of world history, in many cases "the world" has still been studied as a mere backdrop for national and civilizational histories to understand their formations and dynamics (DIRLIK 2005, p. 395).

This state of affairs has notably altered only from the 1980 s onwards. On the one hand, boosted by postmodernism and what is known as the linguistic turn, the "Orientalist" critique of Edward Said, postcolonialism, and the Subaltern studies have posed a profound challenge to European historical methods 
and analytical categories as well as the alleged "Western idea of history" as a whole (e.g. NANDY 1995, p. 44-46, 53-54, 63). On the other hand, the practitioners of world history or global history ${ }^{1}$ have emphasized the entangled and interconnected history of "the West and the rest". For instance, the historian Sanjay Subrahmanyam has used historiographical examples from Mexico, the Mughal empire, and the Ottoman domains to show that there is no such thing as a "European" or "Western" historical consciousness, since the past traditions of history-writing have developed within diverse processes of engagement and supralocal connections at least since the early modern period. Accordingly, he also questions the boundaries defined retrospectively by post-WWII Area Studies, arguing that they have blinded us to the possibilities of connection (SUBRAHMANYAM 1997, p. 742-748, 759-761; 2005, p. 26-30, 35-36). In a similar manner, the world historian Arif Dirlik suggests that we should actually supplant the term "transnational" by "translocal". The latter carries us from the conceptual realm of nations to that of places and spaces which have preceded in their existence the emergence of nations and are quite likely to outlast the nation as we have known it (DIRLIK 2005, p. 397).

In the case of Europe, the post-Communist, post-Maastricht Treaty era is manifest in slogans such as "Europe of the regions," emphasizing its diversity. For instance, the fall of the Cold War dichotomy between the Eastern Bloc and the Western Bloc has generated the notion of "three historical Europes": a western Europe, a central eastern Europe, and a southeastern Europe, which 246 are argued to have their distinctive civilizational heritages and, thus, different routes to modernity (BLOKKER 2005; DELANTY 2007; TROEBST 2003, p. 183185). At the same time, however, the intensified European integration and the development of European Union (EU) institutions have fostered the idea of a deep-rooted unity of European culture, hoping to establish a shared post-national "EUropean" identity. Since both the diversity and unity doctrines have received their share of criticism, a third alternative has also emerged, promoting "unity in diversity," in which different layers of allegiance constitute "the multiple identity of the contemporary subjects" (e.g. SASSATELLI 2002, p. 435-440).

Moreover, a resurgent, renewed, reinvented, or rediscovered regionality has manifested as an interest in sub-national regions within a nation-state or crossing national boundaries, such as the lands of the Sámi people, the northernmost indigenous people in Europe, which are today divided between four different countries (Finland, Norway, Russia, and Sweden). There the regionalist emancipation has resulted in the emergence of resistant regional identifications and the accusations of "internal colonialism" against "the oppressive center," that is, the nation-states that have advocated the forced integration of the Sámi people in the name of "national unity". The integration process of the European Union has accelerated the disintegration of the nation-states through various EU

\footnotetext{
${ }^{1}$ A conceptual distinction is sometimes made between "world history" and new "global history." For instance, according to the historian Bruce Mazlish, the former is mainly focused on civilizations and historical phenomena that arise on a world scale, whereas the latter deals with the processes that transcend the nation-state framework, thus entering upon the history of globalization (see e.g. MAZLISH 1998, p. 387, 393).
} 
programs that support such sub-national regionalism (See e.g. WINGE 2001, p. 48; TOIVANEN 2003, p. 206-207, 213-215).

In all cases, the underlying skepticism about national history arguably indicates that the development of strong nation-states has reached its zenith after 500 years of almost continuous growth, and the past, the present, and the future of "Europe" are reconsidered in the regional framework, which does not necessarily correspond with the present-day nation-states. Quite often the emphasis on a transnational or translocal space has been considered an enlightened alternative to "impoverished provincial thinking" and methodological nationalism; a moral and intellectual imperative in the suppression of destructive (neo-) nationalism and xenophobic tendencies of present-day Europe. As the advocates of comparative and transnational histories argue, these approaches clearly show that national cases cannot be isolated from others in glorious solitude, which raises the question of whether any "national uniqueness" exists at all (APPLEGATE 1999, p. 1164; STENIUS 2003, p. 20; BALDWIN 2004, p. 4-5). The boldest statements argue that the nation-state paradigm has now ended once and for all, and the historians should therefore abandon nation-states as outdated sites of historical inquiry (APPLEGATE 1999, p. 1157-1165; ARONSSON 2001, p. 14; GREEN 2004, p. 45-46).

As a whole, the rising interest in regionalism seems to be related to the new phase of globalization, which, somewhat analogously to the situation of one hundred years ago, has been accompanied by a "return of space." This has resulted in a spatial turn in the social sciences and the humanities, which lends new importance to the inherent spatiality - or, as some scholars rather prefer to say, placiality ${ }^{2}$ - of human activities. To simplify things slightly, while historians have tended to consider history an account of "change over time," it has been argued that they should focus at least equally on "change through space," that is, on the embodied and emplaced nature of our being-in-the-world, which leads us to rethink human history as place-bound and place-making. Theoretically, the spatial turn is indebted to the critical human geographers such as David Harvey, Doreen Massey, and Edward Soja, who have drawn upon a variety of philosophers and sociologists from the pragmatic-hermeneutic tradition and phenomenology to the Frankfurt School, French poststructuralism, and postcolonial studies. The honor of being a path-breaker is often assigned to the Marxist theorist Henri Lefebvre, who in his La Production de l'espace (1974) convincingly articulated the notion of space as socially produced (ETHINGTON 2007, p. 466-467, 478479, 482-483; CASEY 2007, p. 510; ARIAS 2010, p. 29-31).

Because of the significant influence of various "post-isms" on the spatial turn (e.g. poststructuralism, postmodernism, postcolonialism), this approach has challenged such historicist views that regard places, such as nations, regions, and territories, as pre-given entities that can be treated in purely empirical, and empiricist, terms. On the contrary, it argues that places should be considered to

2 The philosopher Edward S. Casey, among others, has presumed the importance of the distinction between space and place, taking "'space' to be the encompassing volumetric void in which things (including human beings) are positioned and 'place' to be the immediate environment of my lived body" (CASEY 2001, p. 683). 
be in the constant state of "becoming," produced and reproduced in interaction with their surroundings. New spatial conceptualizations may emerge, the old ones may acquire new meanings over a period of time, and some may become marginal to people's lives and disappear. In other words, places are not essences but processes, rooted in social practices, disciplinary power, and ideology (GUSTAFSON 2001, p. 6; ARIAS 2010, p. 30-31; JONES 2011, p. 317-319).

Consequently, there is no reason to postulate that the transnational or translocal regions and region-building would be somehow more "natural" or "disinterested" than the nations and nation-building. To cite the critical geographer David Harvey, "Place, in whatever guise, is like space and time, a social construct [...] The only interesting question that can then be asked is: by what social process(es) is place constructed?" (HARVEY 1996, p. 261). Indeed, both in the era of empires and in the era of modern nation-states, the construction of diverse meso-regions has been an inseparable part of state-building, which indicates that regionalist, imperial(ist), and nationalist projects have been closely interwoven, and these distinctions often collapse when actual examples are looked at (APPLEGATE 1999, p. 1164-1165). Thus, a strong case can be made for approaching both nations and transnational regions as "imagined communities," the existence of which is preceded by the existence of nation-builders and region-builders (NEUMANN 1994, p. 58).

However, while very few historians today would claim that a region or a place has a steadfast essence, it is open to debate whether it is possible 248 to construct a region as if it was an ex nihilo creation. Radical constructivists argue that it is always possible to find some link or pre-history which can be used to justify any region-building project, whereas structuralist approaches emphasize that a region is seldom a totally arbitrary product. In other words, both approaches agree that social, economic, cultural, and political structures and traditions in a given transnational or translocal area do not automatically and naturally result in the emergence of a supranational regional entity and a regional identification. However, the structuralists still argue that some regional conceptions may have a certain degree of construct validity and a historical continuity, based on common historical experiences, historical memory, or to use Reinhart Koselleck's concept - a common Erfahrungsraum in the sense that the societies that form a region have been founded on similar principles, practices, and institutions (GÖTZ 2003a, p. 324-326; STENIUS 2003, p. 21; cf. NEUMANN 1994, p. 73).

In this article, I want to argue the case for a moderate region-building approach, which acknowledges the "imagined" character of translocal regions, yet does not regard them as spatial units that can be constructed on a fully arbitrary basis. A prime example of an unsuccessful attempt to construct a translocal region is the Finnish interwar interest in an "in-between" Europe (Zwischeneurope; Väli-Eurooppa), composed of the new independent small-states after the collapse of the Habsburg, Hohenzollern, Romanov, and Ottoman empires. Although some influential politicians and foreign policy experts did their best to promote this transnational entity, the attempt soon came to grief 
due to the lack of trade relations, common geopolitical interests as well as associations and informal networks on the level of civil society (see SAARIKOSKI 1993, p. 116-120; VARES 2003, p. 248-250, 254-262). As the sociologist Anthony Giddens has argued in his theory of structuration, social structures do not do anything by themselves; they depend on the actions of human subjects in everyday life. Without people who make and remake a certain region on a daily basis it will not gain a socio-spatial significance that is necessary for it to become institutionalized - no matter how eagerly the regionalist ideas would be cherished by some politicians or other elite groups (GIDDENS 1984, p. 2-28; see also CRESSWELL 2004, p. 34-39). In other words, there arguably has to be a double process of both "social spatialization" and "spatial socialization" before a certain population considers themselves to be members of a common spatial unit (see PAASI 1996, p. 7-9; MACLEOD 1998, p. 838-839).

A useful theoretical concept in the discussion on a "Europe of the regions" is the German term Geschichtsregion ('history region' or 'historical region'), which has its origins in the interwar debate on what "Eastern Europe" is. To cite the historian Stefan Troebst, in the German sense of the Geschichtsregion, the term "stands for the construction of a meso-region which over a long period of time is characterized by an individual cluster of social, economic, cultural and political structures and which is larger than a single state yet smaller than a continent." Accordingly, a historical region differs from intra-state and inter-state micro-regions (e.g. Bavaria, Bessarabia) as well as from macro-regions such as continents, world-systems, civilizations, or hemispheres (e.g. Europe, sub-Saharan Africa). As Troebst emphasizes, it is above all a heuristic concept for comparative analysis in order to identify transnational or translocal structures and features common to a constructed meta-region which is in general not congruent with geographical or political boundaries. Thus, it is definitely not to be perceived in an essentialist or even geodeterminist way (TROEBST 2003, p. $173,177)$. In my view, this concept is highly useful in the sense that it allows us to recognize the constructed character of places and regions, yet without treating them as purely imaginary, free-floating signifiers that would appear and exist out of nothing.

\section{Norden as a Historical Region}

In the discussion on European regions, Norden (the North) or the Nordic region - often used as a synonym for Scandinavia in anglophone countries - has been presented as a classic example of the Geschichtsregion (TROEBST 2003, p. 173; see also HILSON 2008, p. 15). To cite the sociologist Amitai Etzioni, "There is no region in Europe and few exist in the world where culture, tradition, language, ethnic origin, political structure, and religion - all 'background' and identitive elements - are as similar as they are in the Nordic region" (ETZIONI 1965, p. 220-221). By "the Nordic region," these authors commonly mean the five independent states of present-day Northern Europe: Denmark (including Greenland and the Faroe Islands as the autonomous parts of the Danish state), Finland, Iceland, Norway, and Sweden. 
Indeed, one may certainly claim that Norden has been produced and reproduced during the centuries through the dynamics of everyday life, routine interactions, and constant encounters. As archeological and historical sources testify, the present-day Nordic region was gradually interwoven into a tight network of economical, social, cultural, and political exchange ever since the Early Middle Ages. The most long-lasting political constellation was the Kalmar Union (1397-1523) that united Denmark (including present-day Norway, Iceland, the Faroe Islands, and Greenland) and Sweden (including the southwestern parts of present-day Finland). In a more recent era, common historical structures and institutions such as a uniform Lutheran state-church, the highly centralized state, the agrarian, pragmatic character of "Nordic Enlightenment," and the relative freedom and early political participation of the land-owning peasants have been emphasized as elements that have left their strong imprint on Nordic people's everyday experiences and mentalities (See e.g. GÖTZ 2003a, p. 328331; STENIUS 2003, p. 21-23; HILSON 2008, p. 11-17).

However, on a closer look, the concept of Norden has referred to anything but a clear-cut geographical entity. Instead, it has been in the constant state of becoming. Until the turn of the eighteenth century, in addition to the present-day Nordic countries, "the North" of Europe also included northern Poland, northern Germany, north-western parts of Russia, the islands of Orkney and Shetland as well as the present-day Baltic countries. This broad conception started to shrink only during the Age of Enlightenment. As a consequence of the Great 250 Northern War (1700-1721), the power balance of Northern Europe had been completely shaken: Sweden and Denmark lost their positions as the dominant players in the Baltic Sea region to Russia and Prussia. The defeat of Sweden against Russia was sealed during the Napoleonic Wars, when Sweden lost the eastern third of its remaining realm. This area was incorporated into the Russian Empire as the autonomous Grand Duchy of Finland in 1809. The ideological process of "othering" Russia was accelerated by the breakthrough of political liberalism and the West-European support for Polish autonomy in the 1830s, which degraded Russia to a reactionary regime belonging to "retarded" Eastern Europe or "barbarian" Asia. As a result, a more restricted conceptualization of Norden was established, separating the present-day Nordic countries both from the Slavic Eastern Europe and the Germanic Central Europe (See e.g. HENNINGSEN 1997, p. 105-107; ENGMAN; SANDSTRÖM 2004, p. 16-18; on a more general level, see also WOLFF 1994.)

Indeed, despite the common Lutheran, agrarian, social, and political structures, practices, and traditions, it is fair to say that until the early nineteenth century, Denmark and Sweden had been bitter political rivals. Only with the Romantic mytho-cultural pan-Scandinavianism, which developed into a political pan-Scandinavianism in the early 1830 s, the idea of an age-old Nordic unity truly made a breakthrough. On the one hand, this transnationalist alternative to the nation-state was based on the argument that Norden actually constituted 
one nation (Volk) united by the common linguistic-cultural heritage, ${ }^{3}$ values, and a shared destiny. On the other hand, pan-Scandinavianism was spurred by the attempts to unify the threats of the Danes in the South (Prussia) and the Swedes in the East (Russia) into one figure of thought. Only at this point a common Nordic past from the Viking Age and the Kalmar Union was constructed and elevated to a central position as an evidence for an age-old Nordic (Old Norse) identity (ØSTERGÅRD 1997, p. 34-39; STRÅTH 2012, p. 26). As noted by the historian Else Roesdahl, even the very terms "Vikings" and the "Viking Age" did not exist in their present meaning before the beginning of the nineteenth century (ROESDAHL 1998, p. 9-11).

After the failure of political pan-Scandinavianism in 1864, when Sweden-Norway refused to give military aid to Denmark in the Second War of Schleswig against Prussia-Austria, pan-Scandinavian visions were replaced by practical Scandinavianism or "Nordism". The idea of a common Nordic identity and past remained, but it was now constructed on the basis of the separate nation-states. In other words, Nordicity as a meso-regional identity was now built into what it meant to be a Dane, Swede, Norwegian, Finn, or Icelander, instead of being an addition to the (primary) national identifications. Consequently, the nation-states became the configurations through which Norden manifests itself to the point that the present-day nation-states have come to appear as natural entities, anachronistically projected onto the older historical periods (STRATH 1993, p. 59; ØSTERGÅRD 1997, p. 42-46, 58-62; JOENNIEMI; LEHTI 2003, p. 133).

The "Golden Age" of this Nordic cross-national identification was arguably the postwar era until the collapse of the Soviet Bloc in 1989-1991. During that time, the Nordic countries in general and Sweden in particular were perceived as the avant-garde of modernity. In the Nordic welfare state ideology, Norden functioned as a demarcation from Europe: a democratic, Protestant, progressive, and egalitarian North against a Catholic, conservative, and capitalist Europe as well as the communist Eastern Bloc (SøRENSEN; STRÅTH 1997, p. 22; MUSIA 1998, p. 1-9). In the Cold War environment, the cooperative image of Norden was not only a favorite subject of bombastic political speeches. The Nordic region was institutionalized, for instance, by the 1952 establishment of the Nordic Council as an inter-parliamentary body and the realization of the Nordic passport union. These were followed by the joint labor market in 1954 and the harmonization of laws, such as the Nordic Convention on Social Security in 1955. As a result, the Nordic region was not only a socio-spatial unit into which its inhabitants were socialized as a part of societal reproduction, but it was also a place that provided a geographically specific set of structures that influenced the everyday lives of ordinary citizens in very concrete ways. Hence, Norden became a "place" in the sense that it also referred to personal experiences

\footnotetext{
${ }^{3}$ Danish, Icelandic, Norwegian, and Swedish languages all belong to the North German language group. The three mainland Nordic languages (Danish, Norwegian, and Swedish) are more or less mutually intelligible. Finnish, instead, belongs to the Uralic family of languages, which sets the Finnish-speaking majority of Finland linguistically apart from other Nordic countries. However, during the peak of pan-Scandinavianism, the educated classes in Finland were still mostly Swedish-speaking or bilingual, so the historical role of different languages should not be exaggerated during that period.
} 
and meanings contained in individual life-histories (On a theoretical level, see MACLEOD 1998, p. 838-839). At this point, at the latest, Norden redeemed its status both as a "native concept" rooted in everyday language and an analytic tool developed by the scholars.

Nevertheless, even during the heyday of sovereign nation-states, Norden continued to be a contested and oscillating space. To begin with, since the days of pan-Scandinavianism, there had been a terminological tension between 'Scandinavia' and Norden. In this context, 'Scandinavia' means a Nordic unification and/or cooperation entity without Finland, whereas Norden includes Finland (STRÅTH 2005). In Iceland, by contrast, the term 'Scandinavia' is often used only to denote the Scandinavian Peninsula, that is, Norway and Sweden (ÁRNASON; WITTROCK 2012, p. 21-22). Moreover, some scholars have distinguished the Atlantic sea-facing Norden (Denmark, Iceland, and Norway) from the land-based Baltic Norden (Finland and Sweden). For instance, during the Cold War, the former three countries became founding members of the North Atlantic Treaty Organization (NATO), whereas Sweden and Finland emphasized their neutrality and "the Nordic balance" which anchored Norden between the two Blocs - although the Treaty of Friendship, Cooperation and Mutual Assistance between Finland and the Soviet Union (1948-1992) certainly had its effects on Finnish politics (NEUMANN 1994, p. 62-63; ØSTERGÅRD 1997, p. 70). To some extent, these divisions are visible even today, since Norway and Iceland have decided to stay outside the European Union, whereas Finland is the only Nordic 2.52 country that is the member of the European Monetary Union (Eurozone).

Furthermore, the late nineteenth century also saw the emergence of a more sinister kind of Nordism. In the academic circles, disciplines such as physical anthropology, race biology, and comparative anatomy produced sweeping racial classifications and typologies, which were further combined with archeological and philological findings. When this "scientific" racism was mixed with Old Norse mythologies, Social Darwinism, and pan-Germanic ideas of the true, unspoiled Germanic peoples of Norden, the result was the idea of a common Aryan/ Germanic/Nordic blood, "the Nordic race," and its racial superiority. During the Nazi regime, this ideological mishmash culminated in "the Nordic idea" (allnordischen Gedanken) as the basis of a German-Scandinavian rapprochement (MUSIA 1998, p. 6-7; WERTHER 2010, p. 70-71). Although the number of convinced Nazis was relatively small in the Nordic countries, the amount of Germanophiles and Nazi sympathizers was much larger, and after 1933, it was often difficult to distinguish these groups from each other (see e.g. HANSSON 2003, p. 191-194). Thus, it is safe to say that all Nordic countries had significant, mostly academic and military communities that supported close German-Scandinavian cooperation on the basis of racial brotherhood. Given the different outcome of the WWII, the Aryan/Germanic/Nordic meso-region might have been institutionalized as the new transnational identification of Norden (MUSIA 1998, p. 6-7).

Finally, the post-1989 era resulted in at least in two different kinds of region-building projects the Nordic countries, both of which challenged, to some extent, the axiomatic position of the nation-states. On the one hand, we can perceive a 
conceptual enlargement of Norden, promoted above all by the Nordic scholars of international relations and geopolitics as the shift "from Nordism to Baltism" and "the return of Northernness". As these slogans indicate, the Nordic countries oriented themselves in the 1990s towards the Baltic countries and Northwest Russia. A notable element of this reorientation was the restructuring of the Nordic Council to advance cooperation with these areas (See e.g. WÆVER 1992, p. 101; JOENNIEMI; LEHTI 2003, p. 136-137; BROWNING 2007, p. 41). On the other hand, the old idea of the Nordic Federation (Förbundsstaten Norden) has been reinvented in order to increase the Nordic influence on the European Union as well as to defend the position of the Nordic region in an intensified territorial competition that stretches across the whole hierarchy of spatial locales, from the smallest locality to the scale of the world economy (WETTERBERG 2010; on a general level, see also SOJA 1989, p. 172-173). Although the suggestion of "the new Kalmar Union" has been labelled by most Nordic politicians as highly unrealistic, it highlights the fact that regional identifications are complex processes, and even if the meaning of "the North" might seem to have expanded recently, the old idea of Norden as a demarcation from the rest of Europe and, especially, from Russia is still lurking in the background (see also BROWNING 2003, p. 48, 52-57).

\section{Norden as a Historiographical Region}

For contemporary historians, it is certainly no news that the academization, professionalization, and institutionalization of history as an academic discipline proceeded in the nineteenth century hand in hand with the rise of modern nationalism. Consequently, it is no news either that the history of Norden or the Nordic region has been largely written from the perspective of the separate nation-states. This has been the state of art even in research focusing on the periods preceding the emergence of the nation-states. For instance, in Swedish historiography the idea of a "Sweden proper" emerged after the Napoleonic Wars as the core meaning of all Swedish history from the dawn of time, largely ignoring the fact that the southwestern part of present-day Finland had been an integral part of "original" Sweden ever since its consolidation in the fourteenth century - and vice versa, since Finnish historiography has also been eager to emphasize the long and glorious past of the Finnish nation (folk) before "the Swedish conquest" (ENGMAN 1994; ØSTERGÅRD 1997, p. 58-59). Similarly, Norwegian historians have been busy demonstrating the unbroken continuity of the history of Norway from the Viking era to the nineteenth century, thereby downplaying the significance of "the 400-year-night" during which the country had been a part of the Danish Realm. In this connection, it is perhaps needless to add that their Danish colleagues, for their part, have only been happy to leave Norway to the Norwegians (KIRBY 1991, p. 10-11; ARONSSON et al. 2008, p. 262). In general, the number of those Nordic historians who have specialized in the history of one of their Nordic neighbours has been very small, and in many cases, these territorial crossings have been met with harsh criticism by the "native" historians (ENGMAN 1991, p. 50-51; TORSTENDAHL 2000, p. 16-17). 
While the tendency to nationalize the past is a common feature in modern historiography, in the Nordic case it has been accompanied by a general consensus among the professional historians that the present-day Nordic countries compose a distinctive historical region (Geschichtsregion) with common social, political, economic, and cultural structures and traditions, and thus, Nordic joint activities within historical research are justifiable and necessary. As early as 1905, this conviction resulted in the first Nordic Meeting of Historians (Nordiske historikermöte), which during the interwar period developed into a truly inter-Nordic event participated by historians from all five Nordic countries (TORBACKE 2005, p. 52-56). In Sweden, the interwar period also saw the foundation of the historical journal Scandia in 1929. As the founders of Scandia boldly stated, "national, political, and religious viewpoints are in contravention of scientific principles". Hence, they looked forward to smoothing the way to a better understanding of a common Scandinavian-Nordic heritage; in this case, via a rigorous process of source criticism and demand for objectivity (KIRBY 1991, p. 9; TORSTENDAHL 2000, p. 4).

As I already mentioned in the previous chapter, the postwar era until the collapse of the Soviet Bloc was in many ways "the Golden Age" of Nordic cross-national identification and cooperation. Consequently, the cooperation between Nordic historians also flourished in an unparalleled way during this period, resulting in new inter-Nordic publications, conferences, and research projects. Firstly, the common Nordic historiographical public space was reasserted by the foundation of Scandinavian Economic History Review in 1953 and Scandinavian Journal of History in 1976. When laying out their guidelines, both journals emphasized the international nature of their topics, which, in principle, made them favourable to comparisons presented in an internationally accessible language. As the names of these publications already indicated, this new lingua franca was English, contrary to the previous decades when German had been the most widely used foreign language of the Nordic historians. However, this tendency toward "anglophonizing" the common Nordic historiographical space was not always positively received. Although it arguably made the Nordic discussion and cooperation easier also for those Finnish-speaking Finns and Icelanders to whom Danish, Swedish, and Norwegian were practically foreign languages, it was also criticized for isolating academic history-writing from the broader Nordic community and weakening the common feeling of Nordicity based on the distinctively Nordic linguistic-cultural heritage (ENGMAN 1991, p. 52-53).

Secondly, the increased cooperation was manifested by new inter-Nordic seminars and workshops. From 1965 to 1993, Nordic historians gathered around the regular meetings of the Nordic Historians' Conference on Historical Method (Nordiska historiska metodkonferenserna), specialized in questions on method and theory. Broadly speaking, the initiative to this new forum stemmed from the emergence of the post-WWII welfare states and the increasing importance of the social sciences, which threatened the traditional position of history as the leading academic discipline of the nation-state. Thus, Nordic historians joined forces to protect the integrity and importance of history as a discipline, eager 
to clarify the relation between history and the social sciences (SIMENSEN; HELLAND 1984; ENGMAN 1991, p. 49; TORSTENDAHL 2000, p. 5-9). Moreover, other specialized forms of cooperation sprang up in various subfields. For instance, the Nordic Women's and Gender Historians' Conference (Nordiska Kvinnohistorikermötet) was launched in 1983. Initially, as the original Swedish title reveals, these conferences aimed at making women and their activities more visible in academic history-writing. In the late-1980s, this rather empirical mission was widened by critical self-reflection and a more theoretical approach on gender issues, whereas the novelty of the new millennium has been men's history, inspired by critical studies on masculinities (HAAVET 2009).

Finally, closer cooperation among Nordic historians was encouraged by using research funding as an incentive. Although there had been some funds available for inter-Nordic research ever since the heyday of pan-Scandinavianism, the funding options for these purposes became firmly institutionalized after the establishment of the Nordic Council in 1952. A landmark in this respect was an agreement on the Nordic Cultural Fund, signed in 1966 to support cultural projects (including research) involving a minimum of three Nordic countries. The Nordic Cultural Fund was complemented by about a dozen bilateral funds in the Nordic region. In 1982, a great leap forward was taken by the Nordic Council as it decided to establish the Nordic Science Policy Council for enhancing co-operation among its member countries, soon followed by the establishment of the Nordic Academy of Advanced Study (NorFA). In the field of the humanities and the social sciences, the Joint Committee for Nordic Research Councils (NOSHS) started its work in 2004, launching its first call for Nordic collaborative research projects (NORDCORP) in 2008. In addition, NOS-HS has supported series of Nordic Exploratory Workshops to promote the development of new research areas and programs. In 2005, yet another Nordic research institution, the Nordic Research Board (NordForsk) was established, and the Nordic Science Policy Council as well as the Nordic Academy of Advanced Study were integrated into it. While the original programs of the latter had been reserved for researchers coming from the Nordic countries alone, the post-1989 conceptual enlargement of Norden was manifested in the fact that the current provisions of NordForsk were opened also to researchers and PhD students in the Baltic countries and Northwest Russia (MUSIAŁ 2009, p. 296-297). ${ }^{4}$

Despite all this toing and froing of historians across the Nordic region, those in favour of truly comparative or transnational research projects and publications have been left with a thing or two to desire. As several participants complained in the $21^{\text {st }}$ Nordic Historians' Conference on Historical Method (1989), the excellent opportunities for going beyond the national framework "were not used to the full extent possible." More often than not, the regionalization of the present-day Nordic countries was taken for granted, which resulted in a plethora of projects, publications, and presentations merely listing the distinctive features 
of various nationally-based case studies. Indeed, even today attempts to write a Scandinavian or Nordic history are often organized as "anthology comparisons," where scholars from the national academies contribute from their distinctively nationalist perspectives, and the actual comparisons are left to the readers. Consequently, the attempts to write a Nordic history from a comparative or transnational perspective have mostly been made by scholars from outside the region (ENGMAN 1991, p. 48-52; KIRBY 1991, p. 10-11; see also HILSON 2008, p. 13-14). In some Nordic countries, particularly in Norway and Finland, the academic alternative to the national framework has rather been local history, and regional approaches have thus mostly been limited to the studies of intra-state micro-regions (see e.g. ARONSSON et al. 2008, p. 272; FORSKNINGSRÅDET 2008, p. 114-121, 152-157).

Looking at the critical assessments of the Nordic historians' conferences, the above notions are repeated. According to the historian Jarl Torbacke, well until the postwar era the participants of the Nordic Meetings of Historians generally expressed strong opposition even to common conference themes, not to mention cross- or trans-Nordic research projects that started to gain support no earlier than the late-1960s. Hence, the main function of the Nordic Meeting of Historians was to offer the historians a common platform where each of them could give a talk on his/her own separate national case-study (TORBACKE 2005, p. 57-58). The same can be said about the Nordic Historians' Conferences on Historical Method. In addition to the general Nordic tendency for preferring empirical research to 256 theoretical analysis, neither method nor theory united historians in one country or in the Nordic region as a whole. Instead, the methodological and theoretical choices mostly reflected the general international trends in the field of history without the emergence of a distinctive "Nordic school" of interpretation (KIRBY 1991, p. 11; TORSTENDAHL 2000, p. 25).

To sum up, in addition to being a historical region, Norden certainly composes a historiographical region with long, well-established traditions of academic cooperation, but this sense of regional community is chiefly based on the assumption of the distinctiveness of each Nordic nation-state. As mentioned above, since the idea of a common Nordic identity has become to be built into what it means to be a Dane, Swede, Norwegian, Finn, or Icelander, much promoted "Nordicity" seems to reveal itself only through the nation-states.

In a defense of the nation-centered Nordic historians, it can be acknowledged that the nation-states, however "imagined" and provisional they may be, do not fade away with a sheer effort of will of the historians. In the everyday realities of politics and culture of the twentieth century, they have played a central role - and still do, despite various globalization processes. This is especially true in the Nordic countries, where the post-WWII welfare regimes have been emphatically welfare states; in other words, based on the strong public sector with little room for the private sector, for philanthropic or voluntary provision, or for the family (see e.g. HILSON 2008, p. 90). Thus, instead of dismissing the nation-states as a nightmare from which we have only recently awoken, what is arguably needed is a critical, comparative approach to a history of national 
historiographies, which also regards the interaction of national history-writing with national narratives of other countries as well as with the parallel processes of translocal connections, cultural transfers, and cross-fertilization.

In the history of Nordic historiography, genuinely comparative and transnational approaches are still relatively new phenomena. A pioneering study is the article "Nordic National Histories" (ARONSSON et al. 2008), which was written as a part of the five-year research program "Representations of the Past: The Writing of National Histories in $19^{\text {th }}$ and $20^{\text {th }}$ Century Europe" funded by the European Science Foundation. Here, four Nordic historians joined forces to offer one of the first overall views on Nordic nationalist history-writing. Another publication worth mentioning is The Cultural Construction of Norden, published already in 1997 as a product of cooperation between two research projects. In this volume, the focus was on the Nordic region-building and the parallel development of nationalism and Nordism in the Nordic countries (See SØRENSEN; STRÅTH 1997).

The research done so far indicates that behind the seemingly endless amount of national peculiarities, variations, and differences, there is also a number of important similarities and common basic assumptions. To some extent, we can thus outline a common view of the past, which has influenced the way the past is conceptualized in the Nordic countries in the present. For instance, in all Nordic countries the myth of a golden age of peasant freedom and equality plays a crucial role in national historiographies, tending to exclude the nobility from the people (folk), while simultaneously emphasizing the Lutheran clergy as an essential part of it (ARONSSON et al. 2008, p. 260, 263-264; see also STENIUS 1997, p. 168-169). On the basis of this "grand narrative," it has been argued in the sociological analysis of the Nordic welfare state that there exists a distinct Scandinavian route - a Nordic Sonderweg - to modern democracy, based on the system of peasant proprietorship and family farms (ALESTALO; KUHNLE 1987, p. 8-13, 37; GÖTZ 2003a, p. 331). Within women's and gender history, a related Nordic theme has been the idea of the "strong, hard-working, and independent Nordic woman," which operates with the distinction between "our" welfare states that foster gender equality and the patriarchal systems of other European regions that oppress women (see e.g. MARKKOLA 1997; GORDON 2007).

To be sure, "the free Nordic peasant" and "the strong Nordic woman" are not entirely mythical creatures. In most parts of the Nordic region, except the continental Denmark, there were, indeed, comparatively speaking far fewer feudal traits than in much of the rest of Europe. Thus, there existed a degree of local self-governance by free-holding peasants who were also entitled to send their representatives to the assembly of four estates (in Swedish, Ståndsriksdagen or Rikets ständer) (See e.g. ÁRNASON; WITTROCK 2012, p. 10). In the case of women, it has been stated that due to the persistent agrarian character of Nordic societies, the spheres of men and women were largely overlapping until the $20^{\text {th }}$ century, which restricted the modern bourgeois/urban division of the feminine private sphere and the masculine public sphere. This relatively undifferentiated state of affairs arguably paved the way for Nordic women to participate early on 
in politics and working life (E.g. SULKUNEN 1987; HIILAMO 2006). Nevertheless, by highlighting different historical evidences, a different narrative is also possible. In an alternative version, the lack of feudal traits in Norden is mostly explained by the fact that the actual conditions of the Nordic peasants were so poor that a "feudal system proper" was unnecessary. In other words, there was no need to bind the peasants to the soil, since there was no place for them to escape (YLIKANGAS 1986, p. 52-57). In a similar vein, it has been argued that the social order placed - and still places - women in such a variety of positions in society that it is pointless to discuss a history of "the Nordic woman" in singular form, which calls into question not only a universal male subject, but also a universal female subject (SULKUNEN 1987; MARKKOLA 1997).

In the scope of this article, it is not possible to go into the details of the Nordic myths of "the free peasant" and "the strong woman." Instead, the point I wish to make is that there is no path dependency between the past and the present and, therefore, no unbroken chain of events leading from the pre-modern agrarian monarchies to the post-WWII welfare states (see also HILSON 2008, p. 16; STRÅTH 2012, p. 31). Thus, when the Nordic historians prefer to detect continuity between the past and the present, it is always a matter of choosing some historical facts and leaving something else out of the story. Similarly, when they start discussing region-building, some subjects, phenomena, and epochs are privileged over others. In this sense, as Arif Dirlik puts it, the past is not just a legacy but also a project, and it is our duty as historians to ask ourselves what

258 our project might be (DIRLIK 2005, p. 410).

\section{Concluding Remarks}

Whoever enters the domain of historical and historiographical regions should be aware of venturing into a vague and oscillating space, which offers no steady ground under one's feet. As the "allnordisch" region-building of the Nazi regime poignantly shows, transnational or translocal regional conceptualizations are not necessarily more "enlightened" alternatives to national(ist) ones. More often than not, they are politically and ideologically loaded constructions that are inseparably interwoven into expansive, imperial, or nationalist projects. Thus, a transnational Nordic perspective on history and the history of historiography is not an alternative to methodological nationalism, but rather another dimension in the critical analysis of constructed and "imagined" identifications and communities. If we assume - as I recommend that we should do - that national and regional conceptualizations are, to a large extent, phenomena of discourse, there is very little room left for anything inherently "Nordic". Instead, the emphasis then shifts to the construction and reproduction of Norden and Nordicity at distinctive junctures in time and place and the diverse purposes it serves.

However, similar to the case of nation-states, the acknowledgement of historical regions as constructions does not mean that these constructions are not based on or do not work in "reality" in a material sense. As common historical experiences are based on the fact that the societies forming a historical region share certain principles, practices, and institutions, they may contribute 
significantly to a common mentality and social relations. In the Nordic case, they contribute to a close interconnection of a strong civil society with a strong state, which has been manifested in a close cooperation between the state and the popular movements. Thus, in the similar manner as the geographers Kirsten Simonsen and Jan Öhman argue for a "Nordic" human geography (SIMONSEN; ÖHMAN 2003, p. 3-4), the analysis of Norden - or any other spatial unit - as a historical and historiographical region should try to combine social constructionism and the critique of essentialism with some kind of ontological realism that does not deny a certain construct validity, historical continuity, and concrete material influences of regional conceptualizations. The result would be a more self-reflective, self-critical awareness of how our own historical research relates to territorial demarcations and regional identifications that have often been taken for granted, instead of acknowledging them as made and in a state of continuous becoming.

\section{Bibliography}

ALESTALO, Matti; KUHNLE, Stein. The Scandinavian Route: Economic, Social, and Political Developments in Denmark, Finland, Norway, and Sweden. In: ERIKSON, Robert (Ed.). The Scandinavian Model: Welfare States and Welfare Research. Sharpe: Armork, p. 3-38, 1987.

APPLEGATE, Celia. A Europe of Regions: Reflections on the Historiography of Sub-National Places in Modern Times, American Historical Review, Oct. 99, Vol. 104, Issue 4, p. 1157-1182, 1999.

ARIAS, Santa. Rethinking Space: An Outsider's View of the Spatial Turn, GeoJournal, 75, p. 29-41, 2010.

ÀRNASON, Jóhann; WITTROCK, Björn. Introduction. In: ÁRNASON, Jóhann Páll; WITTROCK, Björn (Eds.). Nordic Paths to Modernity. New York: Berghahn Books, p. 1-24, 2012.

ARONSSON, Peter. The Nature of States and Regions. Reflections on Territory in Swedish Historiography. In: ELIASSEN, Finn-Einar; MIKKELSEN, Jørgen; POULSEN, Bjørn (Eds.). Regional Interaction in Early Modern

Scandinavia. Odense: Odense University Press, p. 14-40, 2001.

ARONSSON, Peter; FULSÅS, Narve; HAAPALA, Pertti; JENSEN, Bernard Eric. Nordic National Histories. In: BERGER, Stefan; LORENZ, Chris (Eds.). The Contested Nation: Ethnicity, Class, Religion and Gender in National Histories. New York; London: Palgrave Macmillan, p. 256-282, 2008.

BALDWIN, Peter. Comparing and Generalizing: Why All History Is Comparative, Yet No History Is Sociology. In: COHEN, Deborah; O'CONNOR, Maura (Eds.). Comparison and History: Europe in Cross-national Perspective. New York; London: Routledge, p. 1-22, 2004.

BLOKKER, Paul. Post-Communist Modernization, Transition Studies, and Diversity in Europe, European Journal of Social Theory, 8 (4), p. 503-525, 2005. 
BROWNING, Christopher S. The Region-Building Approach Revisited: The Continued Othering of Russia in Discourses of Region-Building in the European North, Geopolitics, Vol. 8, No. 1, p. 45-71, 2003.

. Branding Nordicity: Models, Identity and the Decline of Exceptionalism, Cooperation and Conflict, 42 (1), p. 27-51, 2007.

CASEY, Edward B. Between Geography and Philosophy: What Does It Mean to $\mathrm{Be}$ in the Place-World?, Annals of the Association of American Geographers, Vol. 91, No 4, p. 683-693, 2001.

. Boundary, Place, and Event in the Spatiality of History, Rethinking History, Vol. 11, No. 4, p. 507-512, 2007.

CONRAD, Sebastian. Globalisation and the Nation in Imperial Germany. Cambridge: Cambridge University Press, 2010.

CRESSWELL, Tim. Place: A Short Introduction. Malden, MA: Blackwell Publishing, 2004.

DELANTY, Gerard. Peripheries and Borders in a Post-Western Europe, Eurozine, August 29, 2007. Available at: www.eurozine.com/articles/2007-08-29delanty-en.html (accessed on March 30, 2012).

DIRLIK, Alif. Performing the World: Reality and Representation in the Making of World Histor(ies), Journal of World History, Vol. 16, No. 4, p. 391-410, 2005.

ENGMAN, Max. Historikerna och nationalstaten. In: KVIUM, Christian (Ed.), Historien og historikerne i Norden efter 1965. Oplæg fra den 21. Nordiske fagkonference i historisk metodelære, Åland, 27.-31. maj 1989. Studier i historisk metode XXI. Århus: Aarhus Universitetsforlag, p. 4163, 1991.

. National Conceptions of History in Finland. In: LÖNNROTH, Erik; MOLIN, Karl; BJÖRK, Ragnar (Eds.). Conceptions of National History. Berlin; New York: Walter de Gruyter, p. 49-63, 1994.

ENGMAN, Max; SANDSTRÖM, Åke. Det nya Norden. In: ENGMAN, Max; SANDSTRÖM, Åke (Eds.). Det nya Norden efter Napoleon. Acta Universitatis Stockholmiensis 73. Stockholm: Almqvist \& Wiksell International, p. 9-18, 2004.

ETHINGTON, Philip J. Placing the Past: 'Groundwork' for a Spatial Theory of History, Rethinking History, Vol. 11, No. 4, p. 465-493, 2007.

ETZIONI, Amitai. Political Unification: A Comparative Study of Leaders and Forces. New York: Holt, Rinehart and Winston, 1965.

FORSKNINGSRÅDET. Evaluering av norsk historiefaglig forskning. Oslo: Norges forskningsråd, 2008.

GIDDENS, Anthony. The Constitution of Society: Outline of the Theory of Structuration. Cambridge: Polity Press, 1984. 
GORDON, Tuula. The Nordic Approach to the Promotion of Equality. Paper presented in the ESRC funded seminar series "Public policy, equality and diversity in the context of devolution," 2007. Available at: http://www. docs.hss.ed.ac.uk/education/creid/Projects/07xvi_ESRC_Seminar2_ PaperTGordon.pdf (accessed on June 26, 2012).

GÖTZ, Norbert. Norden: Structures That Do Not Make a Region, European Review of History - Revue européenne d'Histoire, Vol. 10, No. 2, p. 323-341, 2003a.

. Century of Corporatism or Century of Civil Society? The Northern European Experience. In: GÖTZ, Norbert; HACKMANN, Jörg (Eds.). Civil Society in the Baltic Sea Region. Aldershot: Ashgate, p. 37-48, 2003b.

GREEN, Nancy L. Forms of Comparison. In: COHEN, Deborah; O'CONNOR, Maura (Eds.). Comparison and History: Europe in Cross-national Perspective. New York; London: Routledge, p. 41-56, 2004.

GUSTAFSON, Per. Meanings of Place: Everyday Experience and Theoretical Conceptualizations, Journal of Environmental Psychology, 21, p. 5-16, 2001.

HAAVET, Elisabeth. Nyskapning og fellesskap - kjønnshistoriens historie sett gjennom de nordiske kvinnehistorikermøtene, Tidskrift for kjønnsforskning, no. 1-2, p. 110-123, 2009.

HANSSON, Jonas. Sweden and Nazism. In: EKMAN, Stig; AMARK, Klas (Eds.). Sweden's Relations with Nazism, Nazi Germany and the Holocaust: A Survey of Research. Stockholm: Almqvist \& Wiksell International, p. 137-196, 2003.

HARVEY, David. Justice, Nature and the Geography of Difference. Oxford: Blackwell, 1996.

HENNINGSEN, Bernd. The Swedish Construction of Nordic Identity. In: SØRENSEN, Øystein; STRÂTH, Bo (Eds.). The Cultural Construction of Norden. Oslo; Stockholm; Copenhagen; Oxford; Boston: Scandinavian University Press, p. 91-120, 1997.

HIILAMO, Heikki. Ovatko Pohjoismaat enää "pohjoismaisia"?, Janus, No. 3, p. 343-347, 2006.

HILSON, Mary. The Nordic Model. Scandinavia since 1945. London: Reaktion Books, 2008.

JOENNIEMI, Pertti; LEHTI, Marko. The Encounter between the Nordic and the Northern: Torn Apart but Meeting Again? In: LEHTI, Marko; SMITH, David J. (Eds.). Post-Cold War Identity Politics: Northern and Baltic Experiences. London; Portland: Frank Cass, p. 128-156, 2003.

JONES, Rhys. Anssi Paasi. In: HUBBARD, Phil; KITCHIN, Rob (Eds.). Key Thinkers on Space and Place. Second Edition. Los Angeles; London; New Delhi; Singapore; Washington DC: SAGE, p. 315-320, 2011. 
KIRBY, David. Nordic Historiography since 1965. In: KVIUM, Christian (Ed.), Historien og historikerne i Norden efter 1965. Oplæg fra den 21. Nordiske fagkonference i historisk metodelære, Åland, 27.-31. maj 1989. Studier i historisk metode XXI. Århus: Aarhus Universitetsforlag, p. 7-15, 1991.

MACLEOD, Gordon. In What Sense a Region? Place Hybridity, Symbolic Shape, and Institutional Formation in (Post-) Modern Scotland, Political Geography, Vol. 17, No. 7, p. 833-863, 1998.

MARKKOLA, Pirjo. Constructing and Deconstructing the 'Strong Finnish Woman': Women's History and Gender History, Historiallinen Aikakauskirja, Vol. 95, No. 2, p. 153-160, 1997.

MAZLISH, Bruce. Comparing Global History to World History, Journal of Interdisciplinary History, Vol. 28, No. 3, p. 385-395, 1998.

MOMMSEN, Hans. Die Nation ist tot: Es lebe die Region. In: KNOPP, Guido; QUANDT, Siegfried; SCHEFFLER, Herbert (Eds.). Nation Deutschland? München: Ferdinand Schöningh, p. 35-38, 1984.

MUSIA $九$, Kazimierz. Tracing Roots of the Scandinavian Model. Image of Progress in the Era of Modernisation. Working papers "Gemenskaper Gemeinschaften", Volume 17. Florence: European University Institute, 1998. Available at: http://www2.hu-berlin.de/skan/gemenskap/inhalt/ publikationen/arbeitspapiere/ahe_17.html (accessed on March 15, 2012). Reconstructing Nordic Significance in Europe on the Threshold of the 21st Century, Scandinavian Journal of History, Vol. 34, No. 3, p. 286$306,2009$.

NANDY, Ashis. History's Forgotten Doubles, History and Theory, Vol. 34, No. 2, p. 44-66, 1995.

NEUMANN, Iver B. A Region-building Approach to Northern Europe, Review of International Studies, Vol. 20, Issue 01, p. 53-74, 1994.

ØSTERGÅRD, Uffe. The Geopolitics of Nordic Identity - From Composite States to Nation-states. In: SØRENSEN, Øystein; STRÅTH, Bo (Eds.). The Cultural Construction of Norden. Oslo; Stockholm; Copenhagen; Oxford; Boston: Scandinavian University Press, p. 25-71, 1997.

PAASI, Anssi. Territories, Boundaries and Consciousness: The Changing Geographies of the Finnish-Russian Border. Chichester: John Wiley \& Sons, 1996.

ROESDAHL, Else. The Vikings. Second Edition. London: Penguin Books, 1998.

SAARIKOSKI, Vesa. Suomen Väli-Euroopan politiikka ja suhteet 1900-luvulla. In: HURU, Jouko (Ed.). Uuden ulkopolitiikan haasteet. Kekkosen ajasta Koiviston kautta 2000-Iuvulle. Rauhan- ja konfliktintutkimuslaitoksen Tutkimuksia No 53. Tampere: Rauhan- ja konfliktintutkimuslaitos, p. 111-143, 1993. 
SASSATELLI, Monica. Imagined Europe. The Shaping of a European Cultural Identity through EU Cultural Policy, European Journal of Social Theory, Vol. 5, No. 4, p. 435-451, 2002.

SIMENSEN, Jarle; HELLAND, Sten. The Nordic Historians' Conferences on Historical Method, 1965-1983, Scandinavian Journal of History, Vol. 9, No 3, p. 239-253, 1984.

SIMONSEN, Kirsten; ÖHMAN, Jan. Introduction: Is There a 'Nordic' Human Geography? In: ÖHMAN, Jan; SIMONSEN, Kirsten (Eds.). Voices from the North: New Trends in Nordic Human Geography. Aldershot: Ashgate, p. 1-8, 2003.

SMITH, Woodruff D. Politics and the Sciences of Culture in Germany, 1840-1920. New York; Oxford: Oxford University Press, 1991.

SOJA, Edward W. Postmodern Geographies: The Reassertation of Space in Critical Social Theory. London; New York: Verso, 1989.

SØRENSEN, Øystein; STRÅTH, Bo. Introduction: The Cultural Construction of Norden. In: SØRENSEN, Øystein; STR $\AA T H$, Bo (Eds.). The Cultural Construction of Norden. Oslo; Stockholm; Copenhagen; Oxford; Boston: Scandinavian University Press, p. 1-24, 1997.

STENIUS, Henrik. The Good Life Is a Life of Conformity: The Impact of the Lutheran Tradition on Nordic Political Culture. In: SØRENSEN, Øystein; STRÅTH, Bo (Eds.). The Cultural Construction of Norden. Oslo; Stockholm; Copenhagen; Oxford; Boston: Scandinavian University Press, p. $161-171,1997$.

State, Citizenship and Civil Society. In: GÖTZ, Norbert; HACKMANN, Jörg (Eds.). Civil Society in the Baltic Sea Region. Aldershot: Ashgate, p. 17-25, 2003.

STRÅTH, Bo. Den nordiska modellen. Nordisk Tidskrift, 69: 1, p. 55-61, 1993.

. Union och demokrati: De Förenade rikena Sverige-Norge 18141904. Nya Doxa: Nora, 2005.

. Nordic Modernity: Origins, Trajectories, Perspectives. In: ÁRNASON, Jóhann Páll; WITTROCK, Björn (Eds.). Nordic Paths to Modernity. New York: Berghahn Books, p. 25-48, 2012.

SUBRAHMANYAM, Sanjay. Connected Histories: Notes towards a Reconfiguration of Early Modern Eurasia, Modern Asian Studies, Vo. 31, No. 3, Special Issue: The Eurasian Context of the Early Modern History of Mainland South East Asia, 1400-1800, p. 735-762, 1997.

. On World Historians in the Sixteenth Century, Representations, Vol. 91, No. 1, p. 26-57, 2005.

SULKUNEN, Irma. Naisten järjestäytyminen ja kaksijakoinen kansalaisuus. In: ALAPURO, Risto; LIIKANEN, Ilkka; SMEDS, Kerstin; STENIUS, Henrik (Eds.). Kansa liikkeessä. Helsinki: Kirjayhtymä, p. 157-172, 1987. 
TOIVANEN, Reetta. The Saami People and Nordic Civil Society. In: GÖTZ, Norbert; HACKMANN, Jörg (Eds.). Civil Society in the Baltic Sea Region. Aldershot: Ashgate, p. 205-216, 2003.

TORBACKE, Jarl. Hundra år av vetenskaplig gemenskap. 25 nordiska historikermöten, Nordisk Tidskrift 1, p. 52-59, 2005.

TORSTENDAHL, Rolf. Thirty-Five Years of Theories in History: Social Science Theories and Philosophy of History in the Scandinavian Debate, Scandinavian Journal of History, Vol. 25, No. 1-2, p. 1-26, 2000.

TROEBST, Stefan. Introduction: What's in a Historical Region? A Teutonic Perspective, European Review of History - Revue européenne d'Histoire, Vol. 10, No. 2, p. 173-188, 2003.

VARES, Vesa. Rajankäyntiä sivistyksen nimissä. Suomalaiset ja Väli-Eurooppa maailmansotien välillä, Historiallinen Aikakauskirja, Vol. 101, No. 2, p. 248-262, 2003.

WÆVER, Ole. Nordic Nostalgia: Northern Europe after the Cold War, International Affairs 68: 1, p. 77-102, 1992.

WERTHER, Steffen. Nazi, German and Danish Identities in Danish North Schleswig, 1932-38. In: HURD, Madeleine (Ed.). Bordering the Baltic: Scandinavian Boundary-Drawing Processes 1900-2000. Berlin; Münster: Lit, p. 69-104, 2010.

WETTERBERG, Gunnar. För egen räkning. Förbundsstaten Norden, Nordisk Tidskrift 4, p. 365-370, 2010.

WINGE, Harald. Regions and Regional History in Norway. In: ELIASSEN, FinnEinar; MIKKELSEN, Jørgen; POULSEN, Bjørn (Eds.). Regional Interaction in Early Modern Scandinavia. Odense: Odense University Press, p. 4155, 2001.

WITHERS, Charles W. J. Place and the "Spatial Turn" in Geography and History, Journal of the History of Ideas, Vol. 70, Number 4, p. 637-658, 2009.

WOLFF, Larry. Inventing Eastern Europe: The Map of Civilization on the Mind of the Enlightenment. Stanford: Stanford University Press, 1994.

YLIKANGAS, Heikki. Käännekohdat Suomen historiassa. Helsinki: WSOY, 1986. 